\title{
THE EFFECT OF PERFORMANCE AND CORPORATE GOVERNANCE TO RISK DISCLOSURE AMONG LISTED COMPANIES IN MALAYSIA
}

\author{
Ag Kaifah Riyard bin Kiflee ${ }^{1^{*}}$ and Mohd Noor Azli bin Ali Khan ${ }^{2}$ \\ ${ }^{1}$ Faculty of Business Economics and Accountancy, \\ Universiti Malaysia Kota Kinabalu, Sabah, Malaysia. \\ ${ }^{2}$ Azman Hashim International Business School, \\ Universiti Teknologi Malaysia, Johor.
}

\begin{abstract}
The objective of this study was to determine the presence of risk information within the annual report of Malaysian non-financial listed companies and empirically extend the current literature of corporate governance and risk disclosure by incorporating an interaction effect in the model. The study found that listed companies in Malaysia experienced a positive upward trend in terms of risk disclosure practice for 10 years (2008-2017). A total of 166 companies were randomly extracted from Main Board of Bursa Malaysia from 2008 to 2017. This study used content analysis, descriptive statistics and multiple regression to explain the relationship between corporate governance and risk disclosure with the effect of the interaction variable. The study also found positive and significant relationship between board independence, board size and board gender with risk disclosure practice. It is also revealed that attainment discrepancies positively influence the relationship between corporate governance and risk disclosure practices among listed companies in Malaysia.
\end{abstract}

Keywords: risk disclosure, annual report, corporate governance, interaction variable, content analysis

\section{ARTICLE INFO}

\section{Article History:}

Received: 9 February 2020

Accepted: 23 February 2021

Published: 30 April 2021

* Corresponding Author: Ag Kaifah Riyard bin Kiflee. E-mail: agkaifahriyard@gmail.com 


\section{INTRODUCTION}

Accounting scandals at Enron, Parmalat and WorldCom in the past have triggered the question regarding the reliability of companies' annual report as a source of information (Linsley \& Shrives, 2000). These incidents have somehow given a positive feedback on the development of risk disclosure practice as companies are no longer relying on the annual report to channel information but also via other communication channels such as press releases and corporate websites (Linsley \& Shrives, 2000). Jorgensen and Kirschenheiter (2003) and Alkurdi et al. (2019) defined risk disclosure as the form of communication of information which is related to a company's strategies, business operations and external elements that may impair expected outcomes such as the disclosure of company future cash flows. However, it was argued that risk information in the annual report is still vague and ambiguous (Elzahar \& Hussainey, 2012; Konishi \& Ali, 2007). As a result, there has been a significant increase in demand for risk information, notably in the non-financial section of the annual report (Cole $\&$ Jones, 2005). The idea to improve transparency among companies has been supported by the Big 4 firms which in December 2001 had submitted a petition to the US Exchange and Securities Commission requesting for a proper guidance for public listed companies in the US on how to incorporate disclosure statement in the annual reports (Amran et al., 2009). This ignited an interest among researchers to further investigate the disclosure practices of companies especially in the area of social and environmental, intellectual property, and risk management.

In addition, it is also argued that the information asymmetry between management and the market is related to poor disclosure practices by a company (Diamond \& Verrecchia, 1991; Lang \& Lundholm, 1993). It was mentioned in Htay et al. (2012) that a poor disclosure practice by a company is due to a poor corporate governance practice. Mitton (2002) and Ntim et al. (2013) also stated that poor corporate governance practice by companies is one of the contributors to the East Asian crisis of 1997 and the global financial crisis in 2008. They also stated that a company's value is closely related to its disclosure policy and governance settings. Therefore, a company which intends to enhance its value may start practising a comprehensive disclosure of information and improve its corporate governance functions (Lobo \& Zhou, 2001; Mitton, 2002). Akhtaruddin et al. (2009) highlighted 
that corporate governance issues and its relationship to disclosure have become the focal point of researchers, particularly in the post Asian financial crisis in 1997. However, to the best knowledge of the researcher, most of the previous studies focussed on examining the relationship between voluntary disclosure and company specific characteristics (Hossain et al., 1994; Wallance \& Naser, 1995) and less have been conducted between voluntary disclosure and corporate governance. This study, therefore, will focus on the impact of board characteristics such as board independence, board size and board duality to risk disclosure practices among Malaysian listed companies.

In addition, this study also extends the current literature on corporate governance and risk disclosure by incorporating the interaction effect of attainment discrepancy to the relationship between corporate governance and risk disclosure. In order to enhance the disclosure practice of the companies, arguably, attainment discrepancies play a significant role in improving the relationship between corporate governance and risk disclosure. Companies with positive attainment discrepancies tend to practice extra disclosures as a mean to signal manager ability (Al-Maghzom, 2016). It was argued that company disclosure practice is closely related to the performance of company (Elshandidy et al., 2013). It was suggested that a company with better performance tends to disclose more information to signal to the market that the company is doing well (Haniffa \& Cooke, 2002).

To enhance the quality of disclosure, it is crucial for regulatory authorities to adopt a comprehensive disclosure requirements (Akhtaruddin et al., 2009). Jensen and Meckling (1976) documented that poor transparency among companies in an emerging market may contribute to higher information asymmetry and decrease in company value. In Malaysia, the Financial Reporting Act 1997 and Bursa Malaysia listing requirements have clearly stated the need for risk management and proper disclosure among listed companies (Amran, et al., 2009). The listing requirements require all listed companies to disclose their financial and non-financial information in the annual reports to aid stakeholders and potential investors to determine company performance (Amran et al., 2009; Zadeh et al., 2016). However, mere adoption of the disclosure rule may result in a lower quality of disclosure. Therefore, what is required is a rather efficient and effective disclosure monitoring agent such as corporate governance to monitor the 
managers which will result in lowering the agency cost and also improve company image and reputation in the market (Akhtaruddin et al., 2009).

The remaining section of this paper is structured as follows. The next section focusses on theory development and followed by the literature review and research framework development in Section 3. In section 4, the research methodology will be explained followed by the summary in Section 5 .

\section{THEORETICAL LITERATURE}

This section will discuss the underpinning theories used in this study.

\section{The Agency Theory}

Jensen and Meckling (1976) refer to agency relationship as a form of contract between one or more persons (principals) with another party (agent) for some service which involves the transfer of decision making authority from principal to agent. It was stated that the agency cost arises when the agent represented by managers and the principal who are the company shareholders have different preferences on company operations (Shehata, 2014). Jensen and Meckling (1976) mentioned that, agency cost arises due to the separation between ownership and management in which result would be different if the acting manager and the owner are the same person.

It was stated that, in a situation whereby the monitoring mechanisms by shareholders and creditors is missing, the manager has the tendency to perform a self-interest behaviour by withholding or manipulating relevant information for self-interest purposes and disclosing misleading information to the market (Latham \& Jacobs, 2000). Besides, agency cost also arises due to information asymmetry between a manager who can access extra information than shareholders (Jensen \& Meckling, 1976). Therefore, to reduce the agency conflict, optimal contract between shareholders and managers is proposed as a means of bringing shareholders objectives to align with managers' (Healy \& Palepu, 2001). In addition, voluntary disclosure is another way to improve agency cost (Barako et al., 2006) as it signals to the market that the company is doing well (Watson et al., 2002). 
The Agency Theory (AT) focusses on the occurrence and degree of conflict between the principal and agent (Amran et al., 2014). Moreover, it is also mentioned that the AT is concerned with whether the managers are acting for the best interests of shareholders. To reduce agency cost, the company may employ corporate governance as a mechanism to align the interests of shareholders and managers and oversee the manager's selfinterest behaviour. Therefore, this study intends to explain the relationship between corporate governance and risk disclosure with the effect of the interaction variables through the AT.

\section{The Signalling Theory}

The term 'signal' originated from Robert Jervis in 1970 and further discussed by Spence (1973) to explain market reactions. It was stated that high quality companies have the tendency to signal the market regarding their future strategies and disclose the current progress of company activities (Eccles et al., 2001). Spence (1973) stated that the signal is a form of information conveyed to the market which usually contains information about the company. Besides, signal can also be defined as the information conveyed by the agent to the principal in multiple understanding signs (Aryani, 2016). Morris (1987), on the other hand, stated that, it is typical to observe manager signalling activities especially in an information asymmetry market.

According to the Signalling Theory (ST), it is beneficial for the company to practice disclosure as through information disclosure, the company is able to convey their steady performance (Zadeh, 2015). In a volatile business environment, information disclosure by a company is a way of signalling company performance to the market (Zadeh, 2015). It is also argued that disclosure practices could enhance company share price as it is directly associated with the capital market (Zadeh, 2015). Disclosure also acts as the signalling mechanism to the market which will lower the risk and capital cost associated with the company. Singhvi and Desai (1971) found that positive performance experienced by a company will encourage the management to prepare a comprehensive report to attract investors as it will reflect the management remuneration. Besides, it also argued that a profitable company has a greater motivation to signal their high performance in the market by disclosing extra information in the annual report (Wallace et al., 1994; Wallace \& Naser, 1995). 
However, in some situations, the manager may purposely send wrong information diverting from the actual situation (Aryani, 2016). According to Estrada (2011), the vague signal is known as non-verifiable statements. It was mentioned that non-verifiable information can be in the form of either a positive or a negative signal or good or bad news in the annual report. A company may purposely deliver vague information to mask the lower performance experienced by the company (Aryani, 2016). It also states that it is very difficult to ensure the truthfulness of the information disclosed by the management in the annual report. Therefore, this study will employ the ST to explain the level of risk disclosure in the annual report of Malaysian listed companies.

\section{Corporate Governance and Risk Reporting in the Malaysian Context}

The 1990s and 2000s have witnessed a significant amount of international corporate failures that triggered the urgency for good corporate governance, accountability, social duty, higher transparency and proper disclosure practices (King Committee, 2002; Mallin, 2002). Realising the need to have better management, countries worldwide have started to improve their corporate governance (Aguilera \& Cuervo-Cazurra, 2009). However, Ntim et al. (2013) argued that most of the corporate governance reforms were focussed on improving the financial aspect especially those reforms in the Anglo-Saxon countries. It was argued that corporate governance is the means of protecting shareholders from managers intimidation (Mitton, 2002). Akhtaruddin et al. (2009) stated that an increase in information disclosure will improve information asymmetry between shareholders and management which results in enhanced company value.

It was mentioned that corporate governance also acts as the internal control which reduces agency conflicts (Akhtaruddin et al., 2009). It was argued that the manager's opportunistic behaviour, information asymmetry and the tendency to withhold information may be reduced under comprehensive monitoring which results in improvement of corporate disclosure (Ho \& Wong, 2001).

In Malaysia particularly, the government has administered a number of measures to improve the current corporate governance practice and 
disclosure standards (Akhtaruddin et al., 2009). It was stated that the Malaysian Code of Corporate Governance (MCCG) was first introduced in 2000 and is responsible to govern internationally accepted corporate governance best practices among listed companies in Malaysia. The Malaysian Accounting Standard (MASB) derived from the Financial Reporting Act 1997 is responsible to establish and issue accounting standards in Malaysia. It was noted that to oversee MASB performance, the Financial Reporting Foundation (FRF) was established. One of the responsibilities of the FRF is to oversee the standards issued by MASB (Akhtaruddin et al., 2009). However, the FRF does not have the privilege to develop accounting standards.

It appears from this discussion that disclosure could enhance the confidence of current and prospective investors. It also mentioned that a company with a sturdy corporate governance structure is likely to disclose information to attract potential investors (Akhtaruddin et al., 2009; Haniffa $\&$ Cooke, 2002). Therefore, this study will focus on examining the impact of corporate governance on risk disclosure among listed companies in Malaysia.

\section{HYPOTHESIS DEVELOPMENT}

One of the main objectives of this study was to uncover the effect of corporate governance (board characteristics) to the risk disclosure practice in Malaysian listed companies. This study identified three board characteristics (board independence, board size and board gender) which may affect risk disclosure practices. Hypothesis development relating to the independent variables are formulated as follows:

\section{Risk Disclosure}

It has been documented that most of the disclosure studies are conducted in Anglo-Saxon nations and some are derived from the United States (US) (Braam \& Borghans, 2014; Elshandidy et al., 2013; Elzahar \& Hussainey, 2012; Hope et al., 2013; Linsley \& Shrives, 2006) and some conducted in Latin nations (Beretta \& Bozzolan, 2004; Oliveira et al., 2011) and Asia (Akhtaruddin et al., 2009; Amran et al., 2009; Haniffa \& Cooke, 
2002). Generally, most of the studies found that the risk disclosure is generic, ambiguous, insufficient, contain past information and are qualitative in nature which are not aligned with stakeholders' demands (Oliveira et al., 2011).

There are a large number of studies that highlight the ambiguousness and insufficient risk disclosure practices around the nations (Oliveira et al., 2011). Studies conducted by Beretta and Bozzolan (2004) and Lajili and Zéghal (2005) in Italy and Canada respectively found that the risk disclosure practices by the companies are qualitative and rather focus on current and past risks. While, Linsley and Shrives (2006) documented that risk disclosure practices by UK listed companies are more future-oriented and qualitative in nature. Moreover, Kajüter (2006) found that the risk information in the annual reports of German companies were vague and most the information disclosed were inaccurate and ambiguous.

By using the same risk framework employed by Linsley and Shrives (2006) for risk disclosure study in the UK, exploratory study for risk disclosure by Amran et al. (2009) found that the level of information disclosed by Malaysian listed companies is way lower compared to UK listed companies. However, it is expected that over the years, continuous development risk disclosure practice by the Securities Commisions (SC), MCCG and MASB, and other significant events such as a global crisis in 2008 will improve the level of risk disclosure practices by Malaysian listed companies.

\section{Board Independence}

Akhtaruddin et al. (2009) argued that the effectiveness of corporate governance in improving agency conflict between management and shareholder relies heavily on the extent of board independence. Elshandidy et al. (2013) found that the proportion of independent directors on the board influences a company's voluntary and mandatory disclosures. Besides, it also mentioned that an independent director's role in the UK promotes disclosure motivation and improved agency cost (Abraham \& Cox, 2007). Chen and Jaggi (2000) and Cheng and Courtenay (2006) also found that there is a relationship between the number of independent directors on the board and disclosure practices of the company. It was documented that a manager's 
opportunistic behaviour can be reduced through the monitoring activity by independent directors (Florackis \& Ozkan, 2008; Kiel \& Nicholson, 2003; Williams et al., 2006). It is also argued that a higher number of independent directors on the board is capable of improving a company's transparency (Htay et al., 2011). The study also stated that the involvement of the independent directors, promotes disclosure by the management and at the same time reduces information asymmetry.

However, it is also found that boards with higher independent directors tend to have poor disclosure practices due to a complex board structure (Gul $\&$ Leung, 2004). This might be due to the reason that the board relies on the top executive for information and decision making as the independent directors and manager do not share a similar objective (Demb \& Neubauer, 1992) or, due to other issues, the board of directors cannot properly execute their duties (Lin et al., 2003). Leung and Horwitz (2004) discussed that, the probability for an independent director to influence management to practice higher information transparency is lower in the presence of higher director ownership. Nevertheless, it was suggested that due to the higher degree of accountability, independency and responsibility of an independent director, they are more prone to stakeholder's demand for disclosure which at the same time motivates the manager to practice higher disclosure. Therefore, it is expected that a higher proportion of independent directors on the board will enhance disclosure practices in Malaysian listed companies.

$\mathbf{H}_{\mathbf{1}}$ : There is a positive relationship between a higher proportion of independent directors on the board and risk disclosure practices in Malaysian listed companies.

\section{Board Size}

Ji et al. (2015) found that companies with a large board size and a higher proportion of independent directors are less likely to have internal control issues of disclosure practices. This indicates that companies with a large board size do have an extra monitoring agent to oversee managerial behaviour which improves internal control issues and promotes disclosure. It also revealed that a larger board size tends to consist of directors with different backgrounds (Htay et al., 2011). However, Guest (2008) and Jensen (1993) documented that, a large board size will not necessary bring 
a positive result. In the UK, companies prefer to have a smaller board to prevent issues of a complex board structure (Guest, 2008). While, Zaluki and Wan Hussin (2009) also revealed that board size is not significant to the quality of financial disclosure in Malaysian public companies. On the other hand, it was also mentioned that a large board size is associated with ineffective communication and coordination which leads to poor decision making. Besides, previous studies also found that the relationship between board size and information disclosure is mixed (Byard et al., 2006; Cheng \& Courtenay, 2006; Hussainey \& Al-Najjar, 2011).

The AT posits that to lower the agency conflict, companies must improve their corporate governance mechanism and it was argued that a larger board is capable of monitoring managers' self-opportunistic behaviour (Ntim et al., 2013). Xie et al. (2003) mentioned that a larger board is associated with the board's diverse experiences which is capable of handling a manager's self-opportunistic behaviour and improve transparency. It was also documented that for the board to work effectively, it must consist of at least 7 to 8 members (Florackis \& Ozkan, 2008; Jensen, 1993). Therefore, this study posited that:

$\mathbf{H}_{2}$ : There is a negative relationship between a larger board size and risk disclosure practices in Malaysian listed companies.

\section{Board Gender Diversity}

Al-Shaer and Zaman (2016) examined the relationship between multi-gender boards and sustainability reporting and discovered that the existence of female directors on the board is associated with a higher quality of sustainability reporting. Independent female directors arguably have a higher tendency to demand for better and sustainable reports due to their background, skills and career experiences (Al-Shaer \& Zaman, 2016; Liao et al., 2015). It was also stated that problem solving skill in a multigender board is rather effective as the issues were solved based on different perspectives suggested by the multi gendered directors. However, despite the positive association between a multi gender board and sustainability reporting quality, it has to be noted that the relationship may also be influenced by the number of directors on the board (Al-Shaer \& Zaman, 2016; Michelon \& Parbonetti, 2012). 
Previous empirical literature on multi-gender board suggest that the existence of female directors on the board could bring both a positive and negative impact to a company. It was argued that a multi-gender board may come up with new ideas and different perspectives which arguably enhance the effectiveness of the board, but also at the same time, the presence of multi-gendered directors also bring negative impacts due to conflicts and role restrictions (Boone \& Hendriks, 2009; Mannix \& Neale, 2005; Ray, 2005). Ray (2005) suggests that a multi-gendered board composition is more likely to bring harm than good to the company as there is a tendency of multi-gender directors to harass each other's opinions due to their different background and experience. Therefore, this study expects that the existence of multi-gender directors on the board may improve the total disclosure practice in a company.

$\mathbf{H}_{3}$ : There is positive relationship between a multi-gendered board and the disclosure practices in listed companies in Malaysia.

\section{Attainment Discrepancy and Risk Disclosure}

The failure of corporate governance has become the center of discussion in the late of 1990s following the financial crisis in 1997-1998 in Asian countries. It was suggested that to have transparent information a company must have a reliable corporate governance structure (Htay et al., 2011). In addition, the stability of company value and market share is measured through the effectiveness of a company's corporate governance. In Malaysia, it was argued that the listed companies are associated with corporate governance issues (Ali, 2013). Some of the problems are excessive government intervention, major involvement of owners in management operations and weak enforcement of the legal system which weakens the corporate governance system (Chu \& Cheah, 2006; La Porta et al., 1999).

To improve disclosure practices among Malaysian listed companies, it is posited that the performance of the company plays a significant role in the relationship between corporate governance and disclosure practice. It was documented that managers of a high performance companies have a greater incentive to disclose their performance to the market (Al-Maghzom, 2016). It was also highlighted that a high performance company will increase its disclosure practice due to a superior image built from a positive performance 
(Iatridis, 2008). Thus, a manager may use the opportunity of a superior image created from high performance, to enhance disclosure practices as it will attract new investments.

As most of the previous studies examine the relationship between company performance and disclosure, studies regarding the effect of attainment discrepancy on the relationship between corporate governance and risk disclosure is still limited. From an analysis, it was found that most of the attainment discrepancy studies were conducted in a field other than corporate disclosure. For example, Arora and Dharwadkar (2011) who employed attainment discrepancy and organisational slack as the interaction variable between corporate governance and corporate social responsibility (CSR) found that, the interaction variables are affecting the relationship between the two. Elgergeni et al. (2018) found that positive attainment discrepancy and lower organisational slack positively affectes the relationship between corporate governance and CSR during the austerity period of 2007-2008.

Previous empirical literature has examined the effect of company performance to risk disclosure practices. The disclosure study for multinational companies by Gray and Roberts (1989), was found that there is a relationship between company performance and disclosure practices. The result aligns with studies conducted by Barako (2007) and Uyar and Kiliç (2012) who documented that a higher performance will influence the company's disclosure level. Elshandidy et al. (2013) also revealed a positive relationship between company performance and disclosure practices in the UK FTSE companies. Elzahar and Hussainey (2012) however stated that, company performance and disclosure is likely to generate a positive and significant relationship due to poor quality information disclosed in the annual report. This aligns with Aljifri et al. (2014) who found no association between company disclosure and performance achieved.

Lant (1992) discussed the impact of performance and introduced the performance concept as an 'attainment discrepancy' which is further explained as a contrast between actual and expected performance. It also highlighted that attainment discrepancy is represented by 'company performance' (Lant, 1992). In a positive attainment discrepancy situation, a company's actual performance exceeds the objective while a negative 
attainment discrepancy was associated with company underperformance (Arora \& Dharwadkar, 2011). The ST posited that, companies have a higher tendency to signal their quality to the market when they achieve a positive performance (Watson et al., 2002). Gupta and Sharma (2014) and Singhvi and Desai (1971) argued that companies tend to disclose extra information when their performance is relatively higher than the industry average which indicates that they are capable of managing risks. Therefore, it is posited that attainment discrepancy positively interacts with the relationship between board independence and disclosure practices:

$\mathbf{H}_{4}$ : Attainment discrepancy positively interacts with the relationship between board independence and disclosure practices

\section{METHODOLOGY}

\section{Sample Selection}

The sample for this study incorporated all the non-financial listed companies in Malaysia from 2008-2017. However, companies with incomplete sets of annual reports were excluded from the list of sample (Amran et al., 2009). This study employed a company's annual report as the unit of analysis to determine risk disclosure information among listed companies in Malaysia similar to the study conducted by Amran et al., (2009) and Zadeh (2015). A total of 167 companies were selected randomly from both the main board and the second board. This study also excluded financial, open and close funds, and insurance companies due to their special disclosure regulations.

\section{Method of Analysis}

To analyse risk disclosure in this study, the content analysis method was employed (Amran et al., 2009; Oliveira et al., 2011). This method was chosen as the purpose of the study was to examine the level of information disclosure by listed companies in Malaysia and not to examine the quality of the information disclosed (Amran et al., 2009). Content analysis is the most popular and common method employed by previous studies to determine information disclosure of a company (Haniffa \& Cooke, 2002; Raar, 2002; Amran, 2006). Content analysis is defined as a method that employed a set 
of procedures to make a valid inference from the text (Weber, 1990). The study also stated that the identification of risk sentences is very subjective depending on the researcher's initial idea, knowledge and preferences. Content analysis allows for repetitive analysis and drawing of a valid inference from the data based on the context (Krippendorff, 1980). To ensure that the method draws valid inference, this study adopted the risk framework and decision rules designated by Abraham and Cox (2007) and Oliveira et al. (2011). Through this method, the risk sentence was identified from the annual report and categorised according to its nature. This study only determined the risk information from the non-financial section or narrative part of the annual report aligning with study conducted by Amran et al. (2009). To investigate the level and characteristics of risk information disclosed by the Malaysian listed companies, this study adopted the risk framework established by Oliveira et al. (2011) and semantic properties by Abraham and Cox (2007).

To analyse the risk information in the annual report, this study employed the method used by Abraham and Cox (2007) who employed words as the recording unit and only intended to analyse the narrative part of the annual report. This study focussed on analysing the narrative part or the non-financial section of the annual report and employed sentences as a recording unit, aligning with the study conducted by Amran et al. (2009), Oliveira et al. (2011) and Zadeh et al. (2016). To ensure that the coder is familiar with the risk sentences and produces a reliable coded output, the researcher underwent a 'familiarisation' process whereby, the researcher trained to analyse the risk sentences based on the set bag of keywords and get familiar with the decision rules. To ensure that the analysis was reliable and accurate, the researcher was exposed to different types of risk information and sentences contained in the annual reports. Once the researcher got familiar with the analysis process and decisions rules, the study employed the automated method of the AntWordProfiler, a software to assist the researcher to analyse the risk information through the sentences (Elshandidy et al., 2013; Kothari et al., 2009; Muslu et al., 2015). This software works by identifying the keywords that were listed earlier and the researcher determines the characteristics of the sentences based on the keyword identified. 
Gray et al. (1995) had raised concerns regarding the unit of analysis used in order to examine the total disclosure level of a company. It was argued that, by employing 'sentences' as a basis to analyse and determine risk sentences, the result generated is far more reliable and accurate than employing another unit of analysis (Milne \& Adler, 1999). It was stated by employing the sentences as the unit of analysis, the researcher is able to determine the 'true meaning' behind the sentences and able to determine the true nature of the risk information. Although most of the studies employed sentences as a medium to extract risk information, the use of word or number of pages to determine disclosure level of the company is also commonly employed. Linsley and Shrives (2006) and Milne and Adler (1999) argued that, the usage of the word as a unit of analysis for risk sentences may not be accurate as the word itself does not represent anything unless the word is written with the sentences in proper context. It was also stated that the use of words to measure the total disclosure level may be inaccurate and complex. In addition, the use of the word as a unit of analysis may also be confusing as it is rather difficult to identify which word is to be considered as risk disclosure without referring to the whole sentence (Linsley \& Shrives, 2006).

It was also stated that, the use of plastic grid to analyse risk sentences in the annual report in an effort to capture the risk information may result in lower reliability and accuracy (Amran et al., 2009). This method arguably is beneficial as it is able to include all the present tables and charts to be analysed. However, this method seems impractical when the annual report of the company is full of pictures, have different fonts, and different page sizes. Hackston and Milne (1996) employed three methods of analysis and found a similarity in each of the methods applied whereby there is significant correlation between the predictor and response variables in each of the methods. Therefore, based on the argument stated, it was agreed that by employing sentences as a basis to measure the total disclosure level of the company is much more reliable and in line with the study objectives. The same method has been applied in previous studies by Amran et al. (2009), Oliveira et al. (2011) and Zadeh et al. (2016). 


\section{DATA ANALYSIS AND EMPIRICAL MODELS}

\section{Dependent Variables}

To determine the total level of disclosure for listed companies in Malaysia, this study employed content analysis as a means of analysis. This study adopted the risk framework by Oliveira et al. (2011) which is divided into three categories: financial risk (FR), non-financial risk (NFR) and risk management framework (RMFW). In addition, this study also adopted the four semantic properties developed by Abraham and Cox (2007) that were used in content analysis to determine the total disclosure level by Malaysian listed companies.

1. Economic sign (monetary and non-monetary)

2. Type of measure (backward and forward-looking information)

3. Outlook (beneficial, non-beneficial and neutral)

4. Type of disclosure (mandatory and voluntary)

$$
\begin{aligned}
& \text { TRDL: } \Sigma \mathrm{fr}_{\mathrm{it}}+\Sigma \mathrm{nfr}_{\mathrm{it}}+\Sigma \mathrm{rmfw}_{\mathrm{it}} \\
& i=0 \quad i=0 \quad i=0
\end{aligned}
$$

$\mathbf{f r}_{\mathrm{ij}} \quad$ : Number of sentences related to financial risk information attributes to $t$ and $i$ th companies

$\mathbf{n f r}_{\mathrm{ij}}$ : Number of sentences related to non-financial risk information attributes to $t$ and $i$ th companies

$\mathbf{r m f w}_{\mathrm{ij}}$ : Number of sentences related to risk management framework attributes to $t$ and $i$ th companies

\section{Independent Variables}

Table 1 states the definitions for independent variables, interaction variable and control variables that were used in this study. Moreover, the Table also presents the acronyms that was used to represent the variables employed. 
Table 1: Symbol and Measurement

\begin{tabular}{|l|c|l|}
\hline \multicolumn{1}{|c|}{ Variables } & Symbols & \multicolumn{1}{c|}{ Measurement } \\
\hline Board independence & BID & No. of independent directors on the board \\
\hline Board size & BSze & $\begin{array}{l}\text { Total number of directors sitting on the } \\
\text { board }\end{array}$ \\
\hline Board Gender & BGdr & $\begin{array}{l}\text { 1. No. of female directors on the board } \\
\text { 2. No. independent female directors on } \\
\text { the board }\end{array}$ \\
\hline Attainment Discrepancy & AttDIS & $\begin{array}{l}\text { 1. ROA } \\
\text { 2. ROE }\end{array}$ \\
\hline Company Size & SIZE & Total Assets of the company \\
\hline Leverage & LEV & $\frac{\text { Total Assets } \times 100 \%}{\text { Total Liabilities }}$ \\
\hline
\end{tabular}

\section{Empirical Equation Model}

To determine the relationship between corporate governance attributes and total risk disclosure level of the company, multiple regression was used. This statistical method has often been used by other previous researchers to determine the relationship between corporate governance and risk disclosure (Amran et al., 2009; Haniffa \& Cooke, 2002; Zadeh, 2015). Therefore, based on the discussion of the dependent and independent variables, the following regression model was developed:

\section{Model 1}

Total Risk Disclosure Level (TRDL) $=\bar{\alpha}_{0}+\beta_{1}$ BID $_{\mathrm{i}, \mathrm{t}}+\beta_{2} \mathrm{BSZe}_{\mathrm{i}, \mathrm{t}}+$ $\beta_{3}$ BGdr $_{i, t}+\delta_{1} \operatorname{SIZE}_{i, t}+\delta_{2} \operatorname{LEV}_{i, t}+\mu_{i}+\mu_{t}+\varepsilon_{i, t}$

Where $\alpha 0$ is an intercept, BID (board independence), BSZe (board size) and BGdr (board gender), SIZE (company size), LEV (leverage) and $\mathcal{E}$ is an error term. This study also employed panel data represented through $\mathrm{i}$ (cross sectional) and $\mathrm{t}$ (time series).

This study also proposed to examine the effect of attainment discrepancies on the relationship between corporate governance and total risk disclosure level of the company in Malaysia. It was stated that companies which intend to achieve industry profit tend to learn from their 
past poor performance (Andersen \& Bettis, 2015). Therefore, in order to determine the effect of attainment discrepancies on the relationship between corporate governance attributes and total risk disclosure level, the 'independent variable*AttDIS' was added to the equation model.

\section{Model 2}

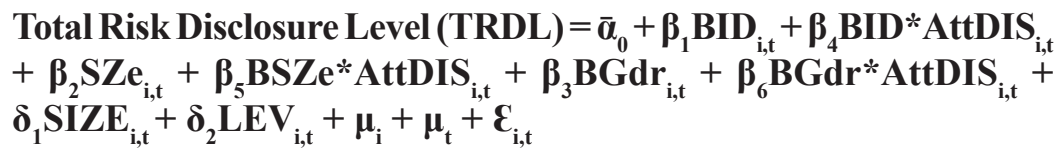

Before performing a robust analysis, the researcher had to ensure that the data fulfills the classical assumption test such as linearity, normality and multicollinearity. The study runs the autocorrelation and variance inflation factor to test if multicollinearity issues exist in the model. This study also conducted normality, linearity and correlation tests to ensure the data was fit and free from correlation issues between the variables to generate robust results (Amran et al., 2009).

\section{EMPIRICAL ANALYSIS RESULT}

\section{Descriptive Statistics and Discussion of Result}

Financial risks come from the financial aspect of the company, and crucially it is very important for the company to disclose their financial risk information such as interest rate risk, foreign exchange risk rate, liquidity risk (Taylor et al., 2010) as this type of information is important to represent the current performance of the company. It was noted that based on Figure 1 , the total disclosure of financial risk in general was on the increase from 2008 to 2017. This can be observed from the mean score recording an increase from 2008 to 2009 (11.693 to 12.014), 13.952 in 2010 and continue to increase until 2017 with a mean of 19.187 . 


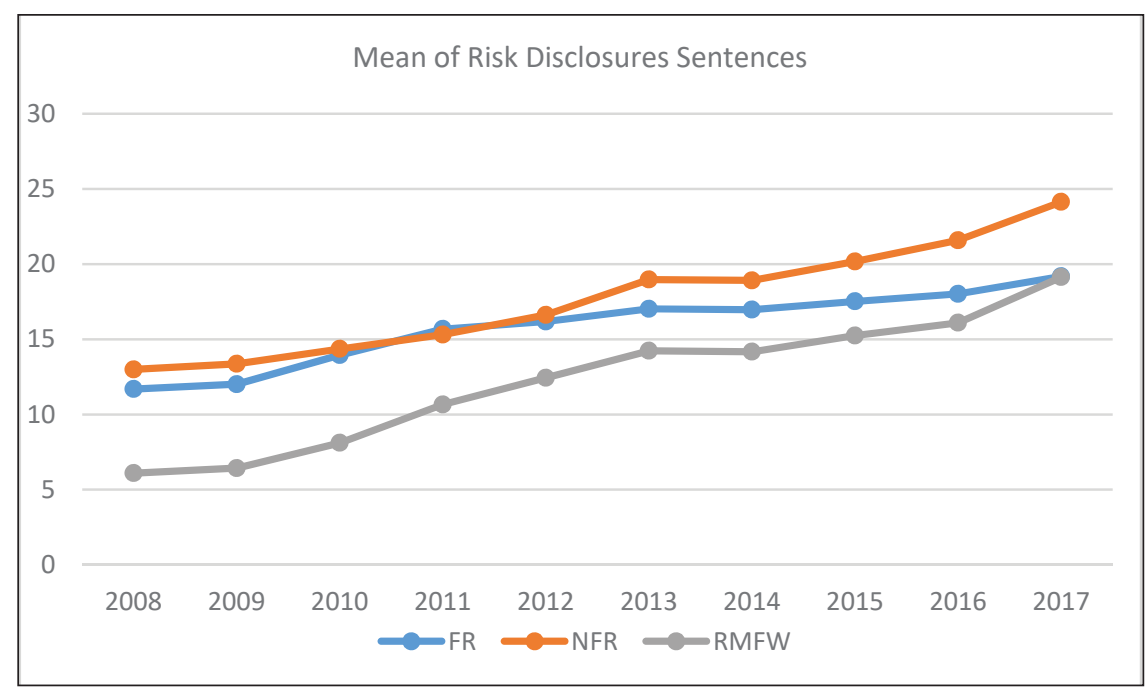

Figure 1: Descriptive Statistics of Risk Disclosure Sentences from 2008-2017

Operational risk, empowerment risk, information processing and technology risk, integrity risk and strategic risk are examples of nonfinancial risks that are usually associated with a company. Non-financial risk information is important for investors to assist them in their investment decision. Operational risk is associated with customer satisfaction, sourcing, high cycle stock, poor products and services, brand erosion and health and safety issues. Based on Figure 1, it is to note that the total disclosure level for non-financial risk information in general experienced a positive trend from 2008-2017. It was recorded that the mean of non-financial information increased from 12.988 in 2008 to 13.367 to 2009, and 14.367 in 2010 and continued to experience a positive trend until 2017 with 24.141 .

Risk management framework can be defined as an action from a risk management committee to lower the risk associated with the company through mitigation plans of identifying, monitoring and managing business risks. RMFW refers to the disclosure of risk management information of a company which is usually presented in the annual report (Oliveira et al., 2011). Even though this type of information is constantly needed from a legitimacy point of view (Bhimani, 2009), previous studies found that the disclosure of this information is unlikely to be understood by the users as 
the nature of this information is very technical and complicated (Oliveira et al., 2011).

Based on the descriptive analysis, it was found that most of the listed companies in Malaysia have a higher tendency to disclose information on non-financial risks than financial risks, and risk management framework information. The result align with the study conducted by Oliveira et al. (2011) who discovered that most of the listed companies in Portugal focus on disclosing non-financial information than risk management framework information. The outcome of this study was expected as Bursa Malaysia through their listing requirements, has listed out the requirement that should be included in the annual report discussion such as industry trend, company performance and economic fluctuation. Based on the study analysis on risk framework of Oliveira et al. (2011), it was found that most of the risk sentences that were identified in the annual report of Malaysian listed companies are non-financial risk information and less on financial and risk management framework information. 


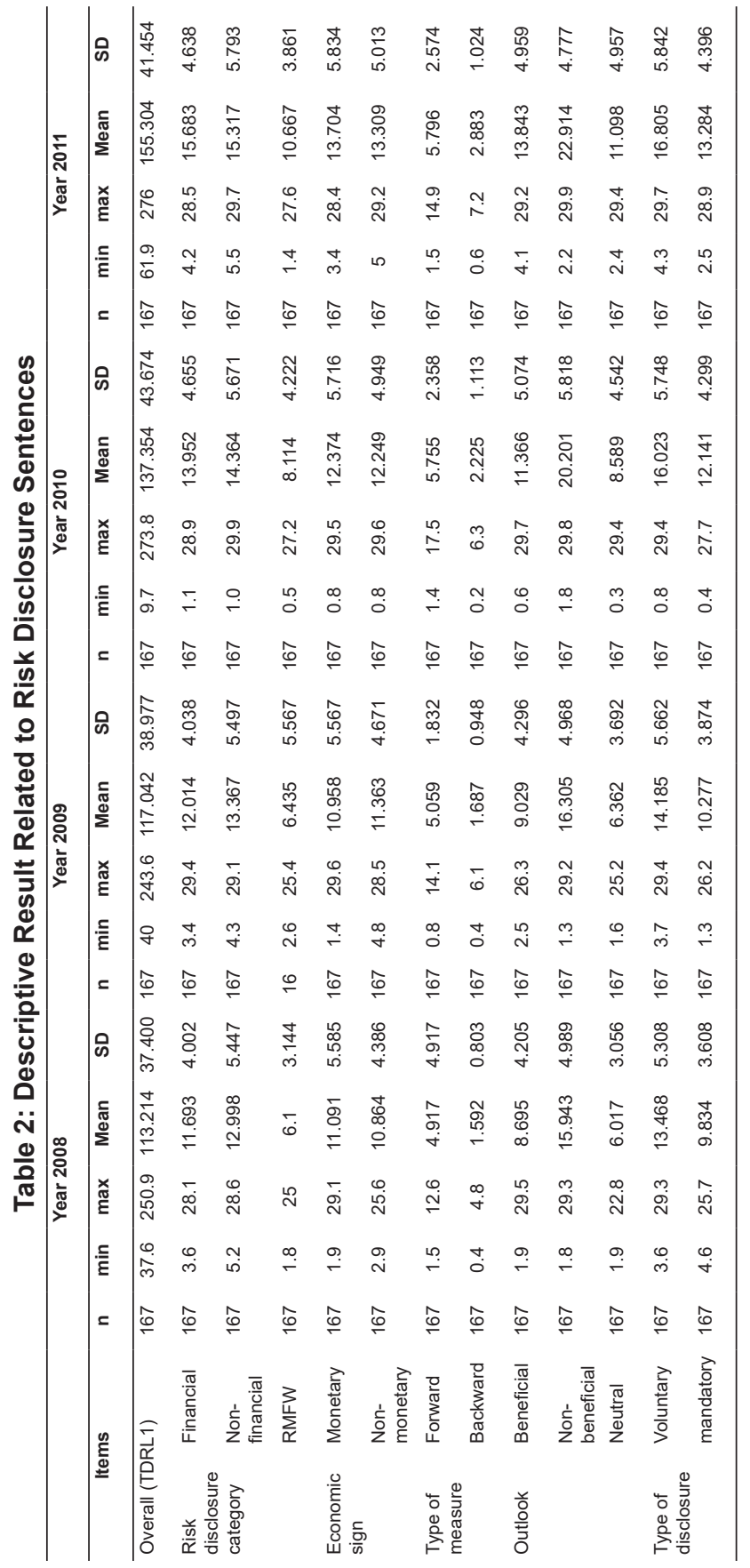




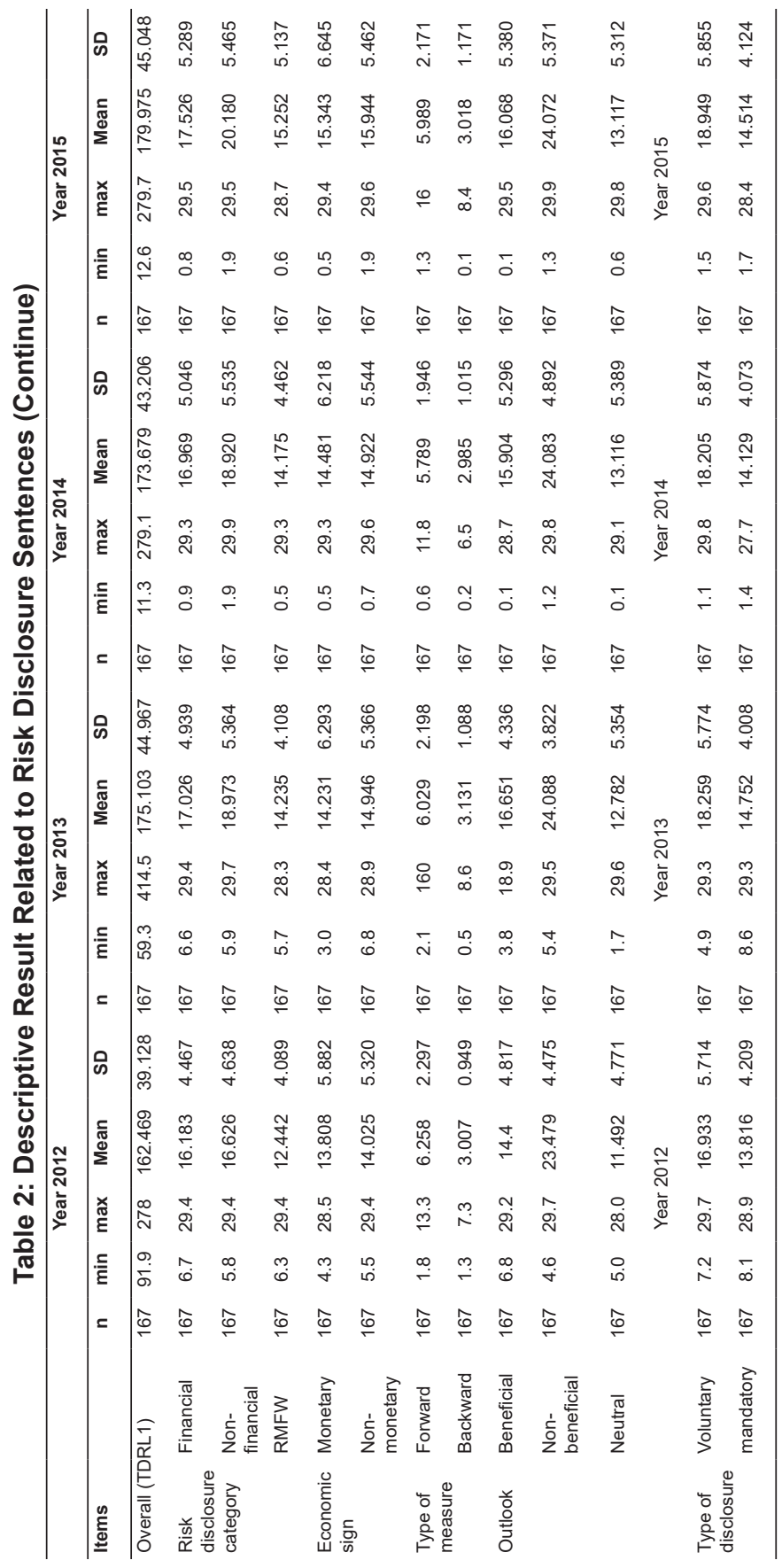




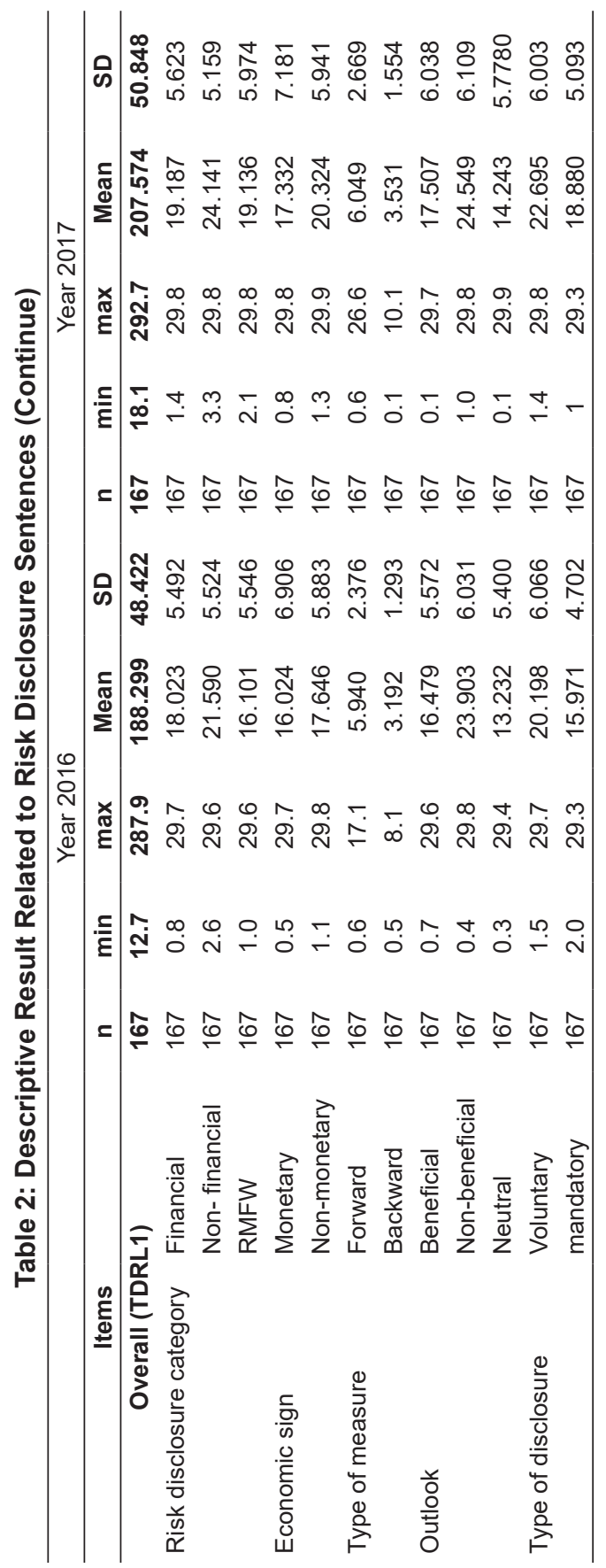


Based on the analysis of the semantic properties of risk disclosure, it was found that most of the companies in Malaysia tend to disclose nonbeneficial information to the market (Figure 2), followed by beneficial news and lastly, neutral information. This can be observed from the mean of the risk which showed a constant increase from 2008 to 2017 (2008: 8.695, 15.035, 6.017, 2009: 9.029, 16.305, 6.362 and 2010: 11.366, 20.201, 8.589). This finding disputes the study conducted by Oliveira et al. (2011) who found that most of the listed companies in Portugal tend to disclose extra information on beneficial news only. In general, risk disclosure is classified as disadvantaged action that reduces transparency of the company as managers have a higher probability to withhold such information from the market. However, this result is in accordance with the study by Ball et al. (2012) who argued that disclosing damaging news is more credible than good news despite the drawback of the information that may lower the quality of the annual report of the company.

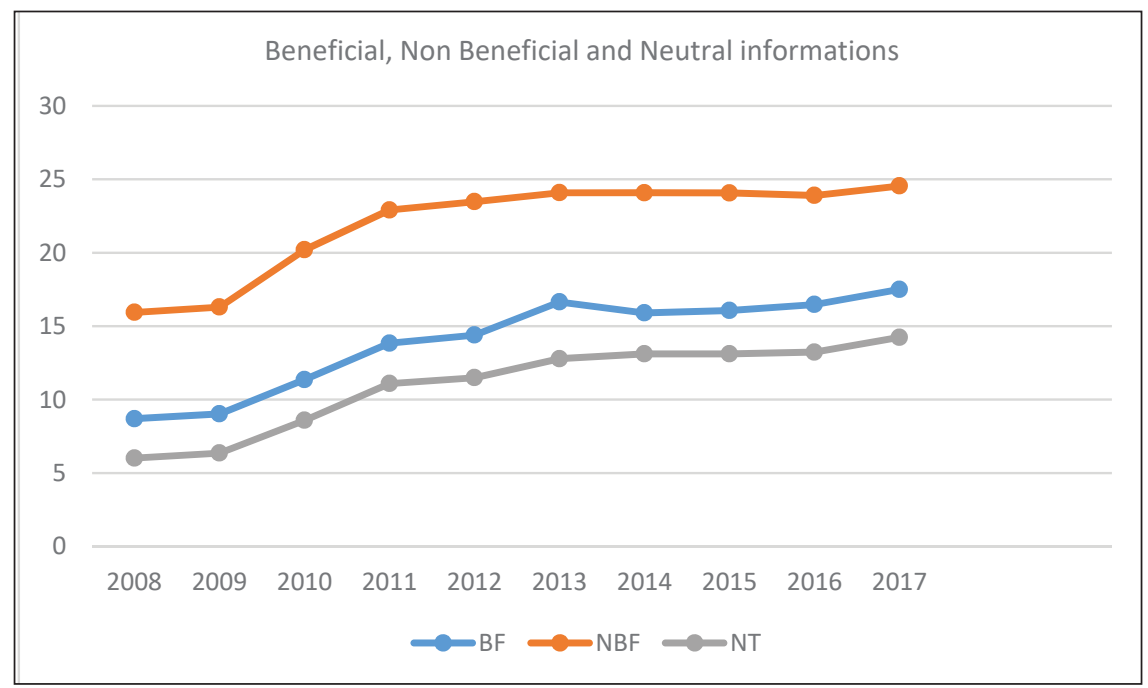

Figure 2: Mean for Beneficial, Non- Beneficial and Neutral Sentences

This is also aligned with the notion that "no news is considered as a bad news' whereby in a situation where the company purposely does not disclose any damaging news, the market tends to interpret the company as hiding problems from reaching them (Lundholm \& Van Winkle, 2006). Therefore, in accordance with the ST, managers may lower their damage 
costs by disclosing damaging news to the market as an act of fulfilling market demands and enhancing their reporting credibility (Deegan \& Gordon, 1996; Skinner, 1994). In addition, it was also noted that the level of neutral information disclosed by Malaysian listed companies had increased in the 10 years and this is in line with study conducted by Zadeh (2015) who also found that, from 2001 until 2011, the level of neutral information disclosed by Malaysian listed companies had increased. By converting the nature of the damaging news into neutral information, a company might be able to preserve the company reputation and enhance investors' confidence.

For the type of measures, the result revealed that most of the Malaysian listed companies considered to disclose forward looking information than backward looking information (Figure 3). The result obtained however, contradicts the study conducted by Oliveira et al. (2011) who argued that most of the listed companies in Portugal preferred to disclose past information in their annual report. The result of this study also refuted findings by Beretta and Bozzolan (2004) and Linsley and Shrives (2006) who found that listed companies in Italy and Canada focussed on disclosing past information in their annual reports.

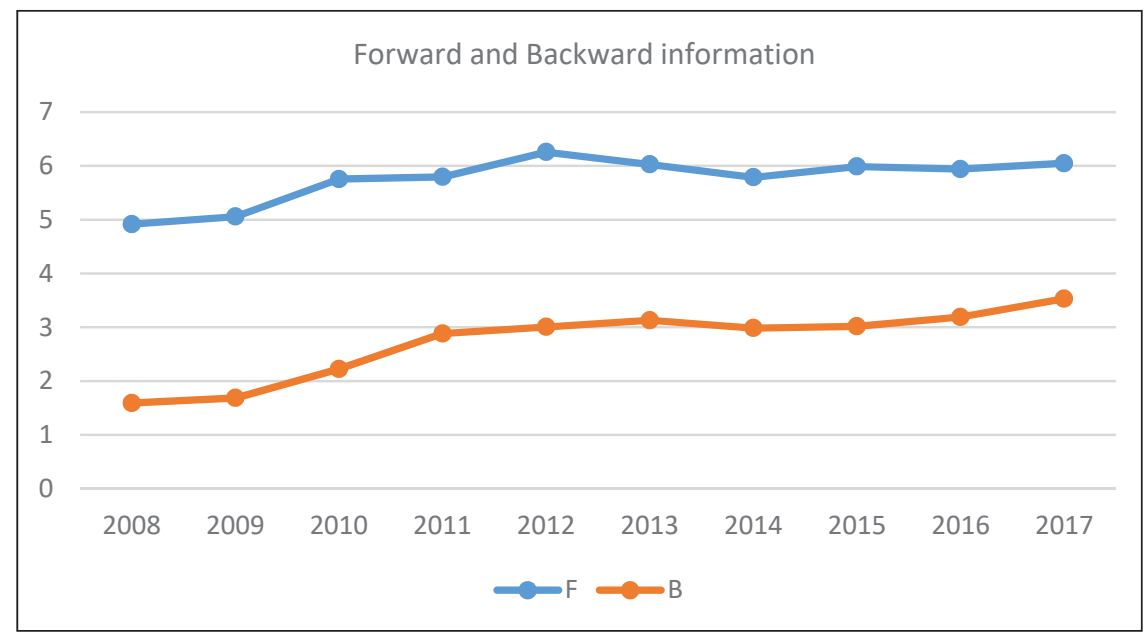

Figure 3: Mean of Forward Looking and Backward Looking Sentences

The result on the disclosure of voluntary and mandatory risk information (Figure 4) suggested that, most of the listed companies in Malaysia tend to disclose information on a voluntary basis. This can be 
observed from the mean of the voluntary disclosure of higher than mandatory disclosure with a score of 22.695 and 18.880. The result is in accordance with the legitimacy point whereby the disclosure of voluntary information is important as it consists of business risks information such as strategic, operational and environmental information (Oliveira et al., 2011). These types of information is important to assist stakeholders to assess the current performance of the company (Oliveira et al., 2011).

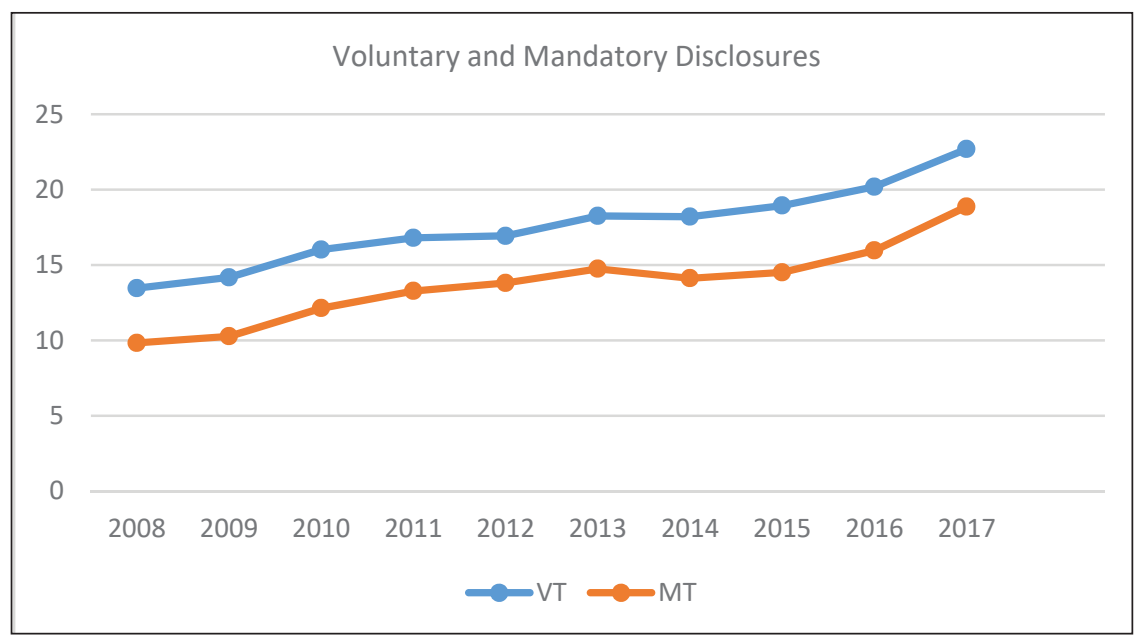

Figure 4: Mean of Voluntary and Mandatory Disclosure Sentences

\section{Multiple Regression}

To determine the interrelationship between corporate governance attributes and the total risk disclosure level of the listed companies in Malaysia, the robustness analysis (fixed effect and random effect) was conducted. The equation models met the fundamental premises as the data were tested for autocorrelation, heteroscedasticity, normality and linearity. The analysis found that board independence and board gender significantly and positively influenced the total risk disclosure level of the company (p-value: 0.001 , p-value: 0.0038 ). While, on the contrary, board size influenced the total risk disclosure level of the company but in the opposite direction (coef: -3.9947, p-value: 0.043). The result suggested that, the larger the board size, the lower the level of total risk disclosure practised by the company. 
Table 3: Model 1 - Regression Result

Model 1

\begin{tabular}{|c|c|c|}
\hline \multicolumn{3}{|c|}{$\begin{array}{l}\text { Total Risk Disclosure Level (TRDL) }=\bar{\alpha}_{1}+\beta_{1} B_{1 D_{i, t}}+\beta_{2} B S Z e_{i, t}+\beta_{3} B G d r_{i, t}+ \\
\delta_{1} \text { SIZE }_{i, t}+\delta_{2} \text { LEV }_{i, t}+\mu_{i}+\mu_{t}+\varepsilon_{i, t}\end{array}$} \\
\hline Independent Variables & Coefficients & P-value \\
\hline BID & 10.0485 & 0.001 \\
\hline Bsze & -3.9447 & 0.043 \\
\hline ToFemDirec & 9.5648 & 0.038 \\
\hline SIZE & $5.91 e-09$ & 0.003 \\
\hline LEV & -0.0042 & 0.783 \\
\hline
\end{tabular}

It was revealed through the analysis that, there is a positive relationship between board independence and the total risk disclosure level of the company in Malaysia. The result suggested that a board with a higher degree of independent directors is more effective in its role, thereby influencing the quality of the financial report (Fama \& Jensen, 1983). In addition, the result is also in line with the AT argument that the existence of independent directors may influence the total risk disclosure practice of the company through their monitoring activity where they monitor the performance of the manager and assess the level of compliance of risk regulations by the company (Donnelly \& Mulcahy, 2008). However, it was stated that the role of independent directors may be effective only in the presence of higher independent directors (Beasley, 1996). This may be due to the reason that, in the presence of lower independent directors on the board, the effect of an independent director may be lower and the probability of disclosure practice of the company to be influenced is lower (Lim et al., 2007).

It was stated that board size plays an important role especially in public listed companies to encourage higher transparency (Elzahar \& Hussainey, 2012). However the result of this study is unaligned with the study proposed by Ntim et al. (2013), Xie et al. (2003) and Zadeh (2015) who argued that board size positively affects the total risk disclosure level of the company. While, on the contrary, Guest (2008) and Jensen (1993) stated that board size may not be necessarily important to determine the level of disclosure practice in one company. It was revealed that companies in the UK rather have a small board size in order to reduce the degree of interference from the management (Guest, 2008). Therefore, based on the argument, it was 
confirmed that a larger board size lowers the transparency of the company and this is represented through the statistical result of the relationship between the board size and the total risk disclosure level of the company in Malaysia (coef: -3.9947, p-value: 0.043). This is due to the fact that the presence of larger board is often linked with poor flexibility and slower decision making (Hussainey \& Al-Najjar, 2011). This as result may impair the quality of information disclosed.

The findings revealed that board gender has a significant positive relationship with the total disclosure level of Malaysian listed companies. This finding agrees with the study conducted by Al-Shaer and Zaman (2016) who found that there is a positive relationship between a multigendered board and sustainability reporting. A board which consists of multi-gendered directors have different personalities, communication skills, expert backgrounds and career experiences which may influence their preference for higher report transparency (Al-Shaer \& Zaman, 2016; Liao et al., 2015). It was also stated that a multi gendered board plays a significant role in encouraging company disclosure practices. It was suggested that the existence of a multi gendered board in a large company will enhance company disclosure practices (Al-Shaer \& Zaman, 2016). This is aligned with the purpose of this study that found that most of the listed companies in Malaysia have acquired profit after tax of at least a minimum of RM20 million for the previous 3-5 years (Bursa, 2018).

\section{Interaction Attainment Discrepancies and the Relationship between Corporate Governance Attributes and Total Risk Disclosure Level (TRDL)}

This study intended to determine the effect of attainment discrepancies and the relationship between corporate governance attributes of board independence, board size and board gender to the total risk disclosure level of the company. The selection of attainment discrepancies in the regression model as interaction variables was based on the significant association between corporate governance attributes (predictor variables) and TRDL (response variable). Based on the result, it was found that attainment discrepancies positively interact the relationship between board independence and board size to the total risk disclosure level of the company. While the relationship between total risk disclosure level and board gender 
was found to have no association with the interaction variable. Therefore, the hypothesis H6 was rejected.

Table 4: Model 2 - Regression Results

\begin{tabular}{|c|c|c|}
\hline \multicolumn{3}{|c|}{ Model 2} \\
\hline \multicolumn{3}{|c|}{$\begin{array}{c}\text { Total Risk Disclosure Level (TRDL) }=\bar{\alpha}_{0}+\beta_{1} \text { BID }_{i, t}+\beta_{4} \text { BID*AttDIS }_{i, t}+\beta_{2} \text { SZe }_{i, t} \\
+\beta_{5} \text { BSZe*AttDIS }_{i, t}++\beta_{3} \text { BGdr }_{i, t}+\beta_{6} \text { BGdr*AttDIS }_{i, t}+\delta_{1} \text { SIZE }_{i, t}+\delta_{2} \text { LEV }_{i, t}+\mu_{i}+ \\
\mu_{t}+\varepsilon_{i, t}\end{array}$} \\
\hline Independent Variables & Coefficients & P-value \\
\hline BID & 0.3959 & 0.001 \\
\hline Bsze & 0.0352 & 0.004 \\
\hline ToFemDirec & 0.2528 & 0.092 \\
\hline SIZE & $5.54 \mathrm{e}-09$ & 0.000 \\
\hline LEV & -0.0053 & 0.128 \\
\hline
\end{tabular}

$\mathrm{H} 4$ posit that attainment discrepancies have a positive interaction on the relationship between board independence and total risk disclosure level. The result in Table 2 showed the coefficient and p-value of the interaction of attainment discrepancies in the relationship between board independence and total risk disclosure level was significant at 0.001 , supporting the hypothesis stated in H4. The result obtained indicated that board independence does have a positive relationship with TRDL but the effect is not strong enough. Therefore, the existence of attainment discrepancies arguably strengthens the role of board independence in encouraging higher disclosure from the company.

It was expected that a board with a higher degree of independent directors is more aggressive with their monitoring activities that may affect the quality of information and later attract the investors (Fama \& Jensen, 1983). However, in the presence of short tenure independent director, the disclosure practice of the company may be affected (Martikainen et al., 2015). High turnover of independent directors also arguably limits the function of the board to fully monitor and determine the risks associated with the company (Martikainen et al., 2015). However, it is observed that a positive performance will encourage the disclosure practice of a company. It was also stated that a company's corporate governance is strengthened through superior performance. Companies with higher profits have the 
tendency to disclose their ability to the market by disclosing good news such as higher profit enjoyment to attract market investment (Al-Maghzom, 2016). This argument is also consistent with Elzahar and Hussainey (2012) who found that the agency cost experienced by the company reduced as the company enjoyed higher performance due to the tendency of the manager to disclose such information to the market, with the intention of signal a positive performance.

H5 expected that there is positive interaction of attainment discrepancies in the relationship between board size and total risk disclosure level of the company. In accordance with Model 1, the size of the board positively influences the total risk disclosure level of the companies in Malaysia. Based on the analysis, it was found that the p-value and coefficient result for Model 2 of the interaction variable was positively significant at 0.004, supporting the H5 of the study. A study by Ji et al. (2015) argued that companies with higher disclosure and lower internal control issues tend to have a large board size and a higher composition of independent directors on the board. However, on a different axis, the presence of a large board size may not bring a positive outcome (Htay et al., 2011). It was argued that the presence of a large board size could bring disagreement and unattended objectives among the directors in the board (Yoshikawa \& Phan, 2003).

It was stated that companies with high profitability have a higher incentive to disclose information related to company risk management (Alzead, 2017). It is also revealed that a company with higher performance may attract the interest of users. The ST also argued that there is a positive relationship between a company's positive performance and the company's higher disclosure practice. From the ST perspective, a manager may intentionally signal the market by disclosing good news to show the market that the company is performing well, with the purpose of attracting investment (Konishi \& Ali, 2007). Therefore, despite the disadvantages of a large board size, the positive performance experienced by the company encourages the manager to disclose higher information to the public.

\section{CONCLUSION}

The objective of this study was to examine the level of disclosure practices and the factors which influence the total risk disclosure level among 
listed companies in Malaysia from 2008-2017. This study focussed on examining the non-financial section of the annual report as the researcher intended to confirm the results attained by Amran (2006) who found that most of the disclosure by Malaysian listed companies were concentrated in the Chairman's statement and is qualitative in nature. In addition, this study also discovered that some of the listed companies in Malaysia put extra effort by disclosing information in the Management, Discussion and Analysis section of the annual report as opposed to the requirement of the accounting standard which requires the information to be disclose at in the Statement of Risk Management and Internal Control section.

Despite an increase in the amount risks disclosed by listed companies in Malaysia, it was found that the number of risk sentence disclosed is still much lower as compared to previous studies (Elzahar \& Hussainey, 2012; Linsley \& Shrives, 2006). The lower level of information disclosed by Malaysian listed companies should not occur as the authorities have put in effort to improve the disclosure practices among listed companies in Malaysia. The relevant parties, especially the regulatory bodies should revise the current disclosure practice abide to the listed companies in Malaysia to ensure the level and amount information disclosed is sufficient and comprehensive.

It was also found that board independence, board size and board gender do influence the total disclosure level of the company in Malaysia. It was discovered that a higher number of independent directors on the board influences the total disclosure practice among listed companies in Malaysia as there are extra monitoring mechanisms present on the top of the company to fully monitor managers' performance and encourage disclosure practices. Moreover, the presence of female directors was also found to have positive relationship with total risk disclosure of the companies in Malaysia. This may be due to the different background possessed by different gendered directors that enhances the effectiveness of the board.

The findings also suggest that attainment discrepancies positively interact with the relationship between board independence and board size and with total risk disclosure levels. However, the study found that there is no interaction between attainment discrepancies and the relationship between board gender and total risk disclosure level. This study sets out an 
important implication that positive attainment discrepancies could improve the corporate governance effect on total risk disclosure level of a company.

To conclude, this study extends the existing disclosure studies by incorporating the interaction variable of attainment discrepancies to the relationship between corporate governance attributes and total risk disclosure level of the companies in Malaysia. This study also found that from 2008-2017, the level of information disclosure among listed companies in Malaysia had experienced a positive upward trend. However, this study also encountered several limitations. First, the subjectivity of the methodology (content analysis) could affect the reliability of results. Second, this study only focussed on the non-financial listed companies in Malaysia and not extended to other industries such as financial and insurance companies which may affect the generated results. Future researches may want to examine other factors that may influence the total risk disclosure levels of a company, other than those stated in this study.

\section{ACKNOWLEDGEMENT}

This paper is the revised version of paper presented at the International Research Conference on Economics, Business and Social Sciences on $3^{\text {rd }}$ November 2018 at Universiti Malaya, Malaysia.

\section{REFERENCES}

Abraham, S., \& Cox, P. (2007). Analysing the determinants of narrative risk information in UK FTSE 100 annual reports. British Accounting Review, 39(3), 227-248.

Aguilera, R. V., \& Cuervo-Cazurra, A. (2009). Codes of good governance. Corporate Governance: An International Review, 17(3), 376-387.

Akhtaruddin, M., Hossain, M. A., Hossain, M., \& Yao, L. (2009). Corporate governance and voluntary disclosure in corporate annual reports of Malaysian listed firms. Journal of Applied Management Accounting Research, 7(1), 1-20. 
Ali, M. M. (2013). Corporate risk disclosure, upper management characteristics, ownership structure and firm value: Malaysian evidence (Doctoral dissertation, RMIT University, Australia).

Aljifri, K., Alzarouni, A., Ng, C., \& Tahir, M. I. (2014). The association between firm characteristics and corporate financial disclosures: evidence from UAE companies. The International Journal of Business and Finance Research, 8(2), 101-123.

Alkurdi, A., Hussainey, K., Tahat, Y., \& Aladwan, M. (2019). The impact of corporate governance on risk disclosure: Jordanian evidence. Academy of Accounting and Financial Studies Journal, 23(1).

Andersen, T. J., \& Bettis, R. A. (2015). Exploring longitudinal risk-return relationships. Strategic Management Journal, 36(8), 1135-1145.

Al-Maghzom, A. (2016). The determinants and consequences of risk disclosure in Saudi Bank (Doctoral dissertation, University of Gloucestershire, United Kingdom).

Al-Shaer, H., \& Zaman, M. (2016). Board gender diversity and sustainability reporting quality. Journal of Contemporary Accounting \& Economics, 12(3), 210-222.

Alzead, R. S. (2017). The determinants and economic consequences of risk disclosure: Evidence from Saudi Arabia (Doctoral dissertation, University of Portsmouth, England).

Amran, A. (2006). Corporate social reporting in Malaysia: An institutional perspective (Doctoral dissertation, University of Malaya, Kuala Lumpur).

Amran, A., Periasamy, V., \& Zulkafli, A. H. (2014). Determinants of climate change disclosure by developed and emerging countries in Asia Pacific. Sustainable Development, 22(3), 188-204.

Amran, A., Rosli, A. M., \& Hassan, C. H. M. (2009). Risk reporting: An exploratory study on risk management disclosure in Malaysian annual reports. Managerial Auditing Journal, 24(1), 39-57. 
Arora, P., \& Dharwadkar, R. (2011). Corporate governance and corporate social responsibility (CSR): The moderating roles of attainment discrepancy and organization slack. Corporate Governance: An International Review, 19(2), 136-152.

Aryani, D. W. I. N. (2016). The determinants and value relevance of risk disclosure in the Indonesian banking sector (Doctoral dissertation, University of Gloucestershire, England).

Ball, R., Jayaraman, S., \& Shivakumar, L. (2012). Audited financial reporting and voluntary disclosure as complements: A test of the confirmation hypothesis. Journal of Accounting and Economics, 53(1-2), 136-166.

Barako, D. G. (2007). Determinants of voluntary disclosures in Kenyan companies annual reports. African Journal of Business Management, 1(5), 113-128.

Barako, D. G., Hancock, P., \& Izan, H. Y. (2006). Factors influencing voluntary corporate disclosure by Kenyan companies. Corporate Governance: An International Review, 14(2), 107-125.

Beasley, M. S. (1996). An empirical analysis of the relation between the board of director composition and financial statement fraud. Accounting Review, 71(4), 443-465.

Beretta, S., \& Bozzolan, S. (2004). A framework for the analysis of firm risk communication. International Journal of Accounting, 39(3), 265-288.

Bhimani, A. (2009). Risk management, corporate governance and management accounting: Emerging interdependencies. Management Accounting Research, 20(1), 2-5.

Boone, C., \& Hendriks, W. (2009). Top management team diversity and firm performance: Moderators of functional-background and locus-ofcontrol diversity. Management Science, 55(2), 165-180.

Braam, G., \& Borghans, L. (2014). Board and auditor interlocks and voluntary disclosure in annual reports. Journal of Financial Reporting and Accounting, 12(2), 135-160. 
Bursa Malaysia. (2018). Main market listing requirement. Exchange Square, Kuala Lumpur: Bursa Malaysia Securities.

Byard, D., Li, Y., \& Weintrop, J. (2006). Corporate governance and the quality of financial analysts' information. Journal of Accounting and Public Policy, 25(5), 609-625.

Chen, C. J. P., \& Jaggi, B. (2000). Association between independent nonexecutive directors, family control and financial disclosures in Hong Kong. Journal of Accounting and Public Policy, 19(4-5), 285-310.

Cheng, E. C. M., \& Courtenay, S. M. (2006). Board composition, regulatory regime and voluntary disclosure. International Journal of Accounting, 41(3), 262-289.

Chu, E. Y., \& Cheah, K. G. (2006). Does ownership structure matter? Evidence from Malaysian equity market. Corporate Ownership and Control, 4(1), 77-90.

Cole, C. J., \& Jones, C. L. (2005). Management discussion and analysis: A review and implications for future research. Journal of Accounting Literature, 24, 135-174.

Deegan, C., \& Gordon, B. (1996). A study of the environmental practices of Australian corporations. Accounting \& Business Research, 26(3), 187-199.

Demb, A., \& Neubauer, F. F. (1992). The corporate board: Confronting the paradoxes. Long Range Planning, 25(3), 9-20.

Diamond, D. W., \& Verrecchia, R. E. (1991). Disclosure, liquidity, and the cost of capital. The Journal of Finance, 46(4), 1325-1359.

Donnelly, R., \& Mulcahy, M. (2008). Board structure, ownership, and voluntary disclosure in Ireland. Corporate Governance: An International Review, 16(5), 416-429. 
Eccles, R. G., Herz, R. H., Keegan, E. M., \& Phillips, D. M. (2001). The value reporting revolution: Moving beyond the earnings game. New York: John Wiley \& Sons.

Elgergeni, S., Khan, N., \& Kakabadse, N. K. (2018). Firm ownership structure impact on corporate social responsibility: Evidence from austerity UK. International Journal of Sustainable Development \& World Ecology, 25(7), 602-618.

Elshandidy, T., Fraser, I., \& Hussainey, K. (2013). Aggregated, voluntary, and mandatory risk disclosure incentives: Evidence from UK FTSE all-share companies. International Review of Financial Analysis, 30, 320-333.

Elzahar, H., \& Hussainey, K. (2012). Determinants of narrative risk disclosures in UK interim reports. The Journal of Risk Finance, 13(2), 133-147.

Estrada, F. (2010). Thomas S. Schelling: Game theory and indirect communication (MPRA Paper No. 34988). Retrieved from https://mpra. ub.uni-muenchen.de/34988/

Fama, E. F., \& Jensen, M. C. (1983). Separation of ownership and control. Journal of Law and Economics, 26(2), 301-325.

Florackis, C., \& Ozkan, A. (2008). Agency costs and corporate governance mechanisms: Evidence for UK firms. International Journal of Managerial Finance, 44(1), 37-59.

Gray, R., Kouhy, R., \& Lavers, S. (1995). Corporate social and environmental reporting: A review of the literature and a longitudinal study of UK disclosure. Accounting, Auditing \& Accountability Journal, 8(2), 47-77.

Gray, S. J., \& Roberts, C. B. (1989). Voluntary information disclosure and the British multinationals: Corporate perceptions of costs and benefits. In A. G. Hopwood (Ed.), International pressures for accounting change (pp. 116-139). Hemel Hempstead, UK: Prentice-Hall International. 
Guest, P. M. (2008). The determinants of board size and composition: Evidence from the UK. Journal of Corporate Finance, 14(1), 51-72.

Gul, F. A., \& Leung, S. (2004). Board leadership, outside directors' expertise and voluntary corporate disclosures. Journal of Accounting and Public Policy, 23(5), 351-379.

Gupta, P., \& Sharma, A. M. (2014). A study of the impact of corporate governance practices on firm performance in Indian and South Korean companies. Procedia - Social and Behavioral Sciences, 133, 4-11.

Hackston, D., \& Milne, M. J. (1996). Some determinants of social and environmental disclosures in New Zealand companies. Accounting, Auditing \& Accountability Journal, 9(1), 77-108.

Haniffa, R. M., \& Cooke, T. E. (2002). Culture, corporate governance and disclosure in Malaysian corporations. Abacus, 38(3), 317-349.

Healy, P., \& Palepu, K. (2001). Information asymmetry, corporate disclosure, and the capital markets: A review of the empirical disclosure literature. Journal of Accounting and Economics, 31, 405-440.

Ho, S. S., \& Wong, K. S. (2001). A study of the relationship between corporate governance structures and the extent of voluntary disclosure. Journal of International Accounting, Auditing and Taxation, 10(2), 139-156.

Hope, O. K., Kang, T., \& Kim, J. W. (2013). Voluntary disclosure practices by foreign firms cross-listed in the United States. Journal of Contemporary Accounting and Economics, 9(1), 50-66.

Hossain, M., Tan, L. M., \& Adams, M. (1994). Voluntary disclosure in an emerging capital market: Some empirical evidence from companies listed on the Kuala Lumpur Stock Exchange. Internal Journal of Accounting, 29(2), 334-351.

Htay, S. N. N., Aung, M. Z., Rashid, H. M. A., \& Adnan, M. A. (2012). The impact of corporate governance on the voluntary accounting information 
disclosure in Malaysian listed banks. Global Review of Accounting and Finance, 3(2), 128-142.

Htay, S. N. N., Rashid, H. M. A., Adnan, M. A., \& Meera, A. K. M. (2011). Corporate governance and risk management information disclosure in Malaysian listed banks: Panel data analysis. International Review of Business Research Papers, 7(4), 159-176.

Hussainey, K., \& Al-Najjar, B. (2011). Future-oriented narrative reporting: Determinants and use. Journal of Applied Accounting Research, 12(2), 123-138.

Iatridis, G. M. (2011). Accounting disclosure, accounting quality, and conditional unconditional conservatism. International Review of Financial Analysis, 20(2), 88-102.

Jensen, M. C. (1993). The modern industrial revolution, exit, and the failure of internal control systems. Journal of Finance, 48(3), 831-880.

Jensen, M. C., \& Meckling, W. H. (1976). Theory of the firm: Managerial behavior, agency costs and ownership structure. Journal of Financial Economics, 3(4), 305-360.

Ji, X. D., Lu, W., \& Qu, W. (2015). Determinants and economic consequences of voluntary disclosure of internal control weaknesses in China. Journal of Contemporary Accounting and Economics, 11(1), 1-17.

Jorgensen, B. N., \& Kirschenheiter, M. T. (2003). Discretionary risk disclosures. The Accounting Review, 78(2), 449-469.

Kajüter, P. (2006, July). Risk disclosures of listed firms in Germany: A longitudinal study. Paper presented at the $10^{\text {th }}$ Financial Reporting \& Business Communication Conference, Cardiff Business School.

Kiel, G. C., \& Nicholson, G. J. (2003). Board composition and corporate performance: How the Australian experience informs contrasting theories of corporate governance. Corporate Governance, 11(3), 189-205. 
King Committee (2002). King Reports on corporate governance for South Africa. Johannesburg: Institute of Directors.

Konishi, N., \& Ali, M. M. (2007). Risk reporting of Japanese companies and its association with corporate characteristics. International Journal of Accounting, Auditing and Performance Evaluation, 4(3), 263-285.

Kothari, S. P., Lu, X., \& Short, J. E. (2009). The effect of disclosures by management, analysts, and financial press on the equity cost of capital. The Accounting Review, 84(5), 1639-1670.

Krippendorff, K. (1980). Content analysis: An introduction to its methodology. London: Sage.

La Porta, R., Lopez-de-Silanes, F., \& Shleifer, A. (1999). Corporate ownership around the world. Journal of Finance, 54(2), 471-517.

Lajili, K., \& Zéghal, D. (2005). A content analysis of risk management disclosures in Canadian annual reports. Canadian Journal of Administrative Sciences / Revue Canadienne des Sciences de l'Administration, 22(2), 125-142.

Lang, M., \& Lundholm, R. (1993). Cross-sectional determinants of analyst ratings of corporate disclosures. Journal of Accounting Research, 31(2), 246-271.

Lant, T. K. (1992). Aspiration level adaptation: An empirical exploration. Management Science, 38(5), 623-644.

Latham, C. K., \& Jacobs, F. A. (2000). Monitoring and incentive factors influencing misleading disclosures. Journal of Managerial Issues, 12(2), 169-187.

Leung, S., \& Horwitz, B. (2004). Director ownership and voluntary segment disclosure: Hong Kong evidence. Journal of International Financial Management and Accounting, 15(3), 235-260. 
Liao, L., Luo, L., \& Tang, Q. (2015). Gender diversity, board independence, environmental committee and greenhouse gas disclosure. British Accounting Review, 47(4), 409-424.

Lim, S., Matolcsy, Z., \& Chow, D. (2007). The association between board composition and different types of voluntary disclosure. European Accounting Review, 16(3), 555-583.

Lin, S., Pope, P. F., \& Young, S. (2003). Stock market reaction to the appointment of outside directors. Journal of Business Finance \& Accounting, 30(3-4), 351-382.

Linsley, P. M., \& Shrives, P. J. (2006). Risk reporting: A study of risk disclosures in the annual reports of UK companies. British Accounting Review, 38(4), 387-404.

Linsley, P., \& Shrives, P. (2000). Risk management and reporting risk in the UK. The Journal of Risk, 3(1), 115-129.

Lobo, G. J., \& Zhou, J. (2001). Disclosure quality and earnings management. Asia-Pacific Journal of Accounting \& Economics, 8(1), 1-20.

Lundholm, R., \& Van Winkle, M. (2006). Motives for disclosure and nondisclosure: A framework and review of the evidence. Accounting and Business Research, 36, 43-48.

Mallin, C. (2002). The relationship between corporate governance, transparency and financial disclosure. Corporate Governance: An International Review, 10(4), 253-255.

Mannix, E., \& Neale, M. A. (2005). What differences make a difference? The promise and reality of diverse teams in organizations. Psychological Science in The Public Interest, 6(2), 31-55.

Martikainen, M., Kinnunen, J., Miihkinen, A., \& Troberg, P. (2015). Board's financial incentives, competence, and firm risk disclosure. Journal of Applied Accounting Research, 16(3), 333-358. 
Michelon, G., \& Parbonetti, A. (2012). The effect of corporate governance on sustainability disclosure. Journal of Management and Governance, 16(3), 477-509.

Milne, M. J., \& Adler, R. W. (1999). Exploring the reliability of social and environmental disclosures content analysis. Accounting, Auditing \& Accountability Journal, 12(2), 237-256.

Mitton, T. (2002). A cross-firm analysis of the impact of corporate governance on the East Asian financial crisis. Journal of Financial Economics, 64(2), 215-241.

Morris, R. D. (1987). Signalling, agency theory and accounting policy choice. Accounting and Business Research, 18(69), 47-56.

Muslu, V., Radhakrishnan, S., Subramanyam, K. R., \& Lim, D. (2015). Forward-looking MD\&A disclosures and the information environment. Management Science, 61(5), 931-948.

Ntim, C. G., Lindop, S., \& Thomas, D. A. (2013). Corporate governance and risk reporting in South Africa: A study of corporate risk disclosures in the pre- and post-2007/2008 global financial crisis periods. International Review of Financial Analysis, 30, 363-383.

Oliveira, J., Rodrigues, L. L., \& Craig, R. (2011). Risk-related disclosures by non-finance companies. Managerial Auditing Journal, 26(9), 817-839.

Raar, J. (2002). Environmental initiatives: Towards triple-bottom line reporting. Corporate Communications: An International Journal, 7(3), 169-183.

Ray, D. M. (2005). Corporate boards and corporate democracy. Journal of Corporate Citizenship, 2005(20), 93-105.

Shehata, N. F. (2014). Theories and determinants of voluntary disclosure. Accounting and Finance Research, 3(1), 18-26.

Singhvi, S. S., \& Desai, H. B. (1971). An empirical analysis of the quality of corporate financial disclosure. The Accounting Review, 46(1), 129-138. 
Skinner, D. J. (1994). Why firms voluntarily disclose bad news. Journal of Accounting Research, 32(1), 38-60.

Spence, M. (1973). Job market signaling. The Quarterly Journal of Economics, 87(3), 355-374.

Taylor, G., Tower, G., \& Neilson, J. (2010). Corporate communication of financial risk. Accounting \& Finance, 50(2), 417-446.

Uyar, A., \& Kılıç, M. (2012). Value relevance of voluntary disclosure: Evidence from Turkish firms. Journal of Intellectual Capital, 13(3), 363-376.

Wallace, R. O., Naser, K., \& Mora, A. (1994). The relationship between the comprehensiveness of corporate annual reports and firm characteristics in Spain. Accounting and Business Research, 25(97), 41-53.

Wallace, R. S. O., \& Naser, K. (1995). Firm-specific determinants of the comprehensiveness of mandatory disclosure in the corporate annual reports of firms listed on the Stock Exchange of Hong Kong. Journal of Accounting and Public Policy, 14(4), 311-368.

Watson, A., Shrives, P., \& Marston, C. (2002). Voluntary disclosure of accounting ratios in the UK. The British Accounting Review, 34(4), 289-313.

Weber, R. P. (1990). Basic content analysis ( $2^{\text {nd }}$ ed.). Newbury Park, CA: Sage.

Williams, D. R., Duncan, W. J., Ginter, P. M., \& Shewchuk, R. M. (2006). Do governance, equity characteristics, and venture capital involvement affect long-term wealth creation in US health care and biotechnology IPOs?. Journal of Health Care Finance, 33(1), 54-71.

Xie, B., Davidson, W. N., \& DaDalt, P. J. (2003). Earnings management and corporate governance: The role of the board and the audit committee. Journal of Corporate Finance, 9(3), 295-316. 
Yoshikawa, T., \& Phan, P. H. (2003). The performance implications of ownership-driven governance reform. European Management Journal, 21(6), 698-706.

Zadeh, F. O. (2015). Corporate governance, risk disclosure and cost of equity capital in the Malaysian public listed firms (Doctoral dissertation, Universiti Teknologi Malaysia).

Zadeh, F. O., Rasid, S. Z. A., Basiruddin, R., Zamil, N. A. M., \& Vakilbashi, A. (2016). Risk disclosure practices among Malaysian listed firms. International Journal of Economics and Financial Issues, 6(3), 10921096.

Zaluki, N. A. A., \& Wan Hussin, W. N. (2009). Corporate boards, audit committees and quality of financial disclosure in IPOs. SSRN eLibr. 